\title{
'Why should I trust you with my money?': credible commitments in the informal economy in China
}

\section{Introduction: Informal Value Transfer Systems}

Informal Value Transfer Systems (IVTS) are unofficial channels of transferring money from one jurisdiction to another through a service provider (Thompson 2008: 94; Siegel and van de Bunt 2014: 252). Before banks existed, these channels were the only way to move value around, and have been documented since antiquity in texts such as the Koran and in Mediterranean societies (Richards 1970; Goitein 1967-93). Even with the advent of regulated national and global banking, these channels still offer informal ways to move money that are ultimately illegalthey breach norms related to money laundering as well as banking rules. IVTS are known by a variety of names around the world: Black Market Peso Exchange (Latin America), Hundi (Burma/Myanmar), Dixia qianzhuang (China), Padala (Philippines), Phei kwan (Thailand), and Hawala (the Arab and Muslim world) (see Ballard 2003: 8; Siegel and van de Bunt 2014: 252; Skarbek 2008; Thompson 2006; Turnell, Vicary and Bradford 2008; van de Bunt 2008: 113).

Today, IVTS are used by migrant workers (Siegel and van de Bunt 2014: 254-9; Skarbek 2008) and in regions where the banking system is virtually non-existent or highly ineffective (or both) such as Syria, Iraq, Afghanistan and Somalia. For instance, there were 13 banks in Kabul in 2005, and between 500 and 2,000 hawala shops in the country (Maimbo 2003: 8; Thompson 2006: 157,$161 ; 2008: 84)$. In these regions, IVTS are used even by international organizations and NGOs (Hariharan 2012; Lindley 2009; Thompson 2008: 84; van de Bunt 2008: 113; see also Ismail 2007).

In the immediate aftermath of the terrorist attack of 9/11 against the US, President Bush suggested that the money used by the hijackers had been transferred using the hawala system. 
The 9/11 Commission Report eventually dismissed this notion (the hijackers had received money through the official banking system) yet it stated that 'Al Qaeda frequently moved the money it raised by hawala, an informal and ancient trust-based system for transferring funds' (NCTA 2004: 171, see also 237, and 498, fn. 124). More generally, IVTS have been under scrutiny as possible conduits of money to fund terrorist activities in the West, Central Asia and the Middle East (Passas 2003). IVTS are also used for criminal purposes, such as tax evasion, ransom payments, human trafficking and smuggling and drugs trafficking (see e.g. Campana 2018; Jost and Sandhu 2000; Kleemans et al. 2002; Passas 1999, 2005; Thompson 2006; van de Bunt 2008).

How do such transactions work? Figure 1 offers a pictorial outline of the key relationships. Customer 1 gives money (or value) to service provider 1, who resides in the same country. At the same time, service provider 1 gives a code to both customer 1 and service provider 2 (who operates in country B). Customer 1 gives the code to her associate, who also resides in Country $\mathrm{B}$ and will collect the money (normally in local currency) from service provider 2, who uses his own cash reserves. At some later point, the debt between service providers will be offset by transactions in the other direction, through formal bank accounts or by delivering commodities of equal value (XX).

(Figure 1 here)

Service provider 1 normally charges a fee or a percentage of the sum transferred (van de Bunt 2008: 116). Profit for service provider 2 comes from choosing a favourable currency exchange rate (Thompson 2006: 165). Ultimately, this system operates outside the scope of the law, although in some contexts it is tolerated (XX. See also Skarbek 2008: 7; Thompson 2008: 100; van de Bunt 2008: 115).

\section{Informal Value Transfer Systems, Trust and Credible Commitments}

Most scholars have noted that trust is critical to the functioning of IVTS, yet it is often unclear what role trust plays. We shall argue below that it has a limited role. What do we mean by trust? 
'Trust takes place within the context of an agreement or a promise: it is the decision by Actor A to transfer resources to Actor B in the expectation that B's action will at a later point in time satisfy the terms of the agreement' (Campana and Varese 2013). Thus, Actor A takes a risk by cooperating first, in the hope that her act will be rewarded by Actor B's behavior. The situation implies a degree of uncertainty over the intentions of Actors B, who has incentives to act dishonestly. This is certainly the case with the IVTS exchange. Customer 1 gives her cash to service provider 1 in the expectation that he will at a later point satisfy the terms of their agreement. More precisely, service provider 1 is expected to order service provider 2 to give the agreed amount to customer 2 . Service provider 2 also needs to trust service provider 1 , as the former must part with his money before receiving the cash from the latter. In short, service provider 1 is the actor who most needs the most to be trusted by everybody involved in the IVTS. Yet, the decision to exchange is based on a rationally formed expectation. Rather than a leap into the dark, customers would look for clues that will give them confidence that service provider 1 will stick to his promise. Rather than just believe in the goodwill of the partner, customers would look for reassurance based on the incentive structure of the service provider. The literature of trust has often conflated these meanings of trust, namely 1) the emotional or irrational expectation of benign behaviour by the partner, what we call 'the leap into the dark' and 2) reassurance based on the incentive of the partner. This second type of trust has been called with different names in the literature, such as 'deterrence-based trust' (Shapiro et al. 1992), 'encapsulated self-interest' (Hardin 1991) and 'assurance', by Yamagishi and Yamagishi (1994), who provide a cogent and clear discussion of the distinction. We will show below that service providers in turn offer a number of 'credible commitments' that underpin their promise and serve to reassure customers. Hence trust plays a very limited role in the decision to use an IVTS.

Authors such as Coase (1937) and North (1993) have emphasized that, when transaction costs are not negligible, institutions can bind players to agreements across space and time (North 1993: 11). In legal markets, economic agents can rely on the state to enforce contracts through an effective court system (Hobbes 1651: ch. 13; Cook, Hardin and Levi 2005: 151-165). If partners do not abide by the contract, they can be simply taken to court. Yet such institutions go only so far: written contracts cannot spell out all possible contingencies (hence they are called 'incomplete', see Hart 1988), and resorting to courts is a costly process (Frye and Shleifer 1997). 
Thus, to varying degrees, trusting others requires a leap of faith even among agents who engage in legal transactions. This is even more true in illegal markets, where by definition the state is not just absent but actively pursuing lawbreakers (at least in theory). Yet even in illegal markets agents have ways to make that leap of faith as small as possible, hence reducing risk of failure. The Mafia and some gangs are organizations able to provide third-party enforcements of deals and promises, although they might be costly and the collective outcome for society is disastrous (Gambetta 1993; Varese 2001; Campana 2011; Skarbeck 2011). In addition, mafias are not universally present. Other, informal ways to foster exchange and allow actors to show that they are committed to their promises exist: reputation-building; repeated interaction; hostage-taking; and sharing compromising information. They are all credible commitments that do not imply the presence of a third-party enforcer of deals and promises. A reputation for fair dealing and keeping one's word is built when future partners are aware of an actor's past behaviour and such knowledge in turn fosters cooperation. Repeated interaction between the individuals involved in several exchanges will provide valuable information to predict future behaviour of the potential partner. When the information is positive, actor A will be inclined to cooperate with actor B. Both mechanisms have attracted a great deal of scholarly attention (e.g. Axelrod 1984; Klein 1997; Raub and Weesie 1990).

The principle behind the next two mechanisms is that it pays to reduce one's options. Hostagetaking, as explained by T.C. Schelling in a series of seminal works (1960, 2006), is a form of credible commitment (Williamson 1983). Taking hostages to guarantee promises has been documented since antiquity as an effective way to seal deals and treaties. For instance, at the end of the Second Punic War in 202 BC, the Romans took hostages from the defeated people and held them in Rome 'to serve as assurances for the post-war settlement' (Allen 2006: 3). Shared ethnic and kinship ties have often been mentioned as a source of trust among those who operate in illegal markets. Kinship can operate as a form of hostage-taking: by entering into a joint project with a member of the same ethnic group or a relative, the parties can ensure effective punishment of the person who defects on the promise. His or her relatives will be easily found and punished, either socially or with the use of violence (Campana and Varese 2013). Sharing of compromising information is an additional mechanism that can foster cooperation. The original 
insight also comes from Schelling (1960), who offers the following hypothetical case of a kidnapper and his prisoner:

Both the kidnapper who would like to release his prisoner, and the prisoner, may search desperately for a way to commit the latter against informing on his captor, without finding one. If the victim has committed an act whose disclosure could lead to blackmail, he may confess it; if not, he might commit one in the presence of the captor, to create the bond that will ensure his silence (Schelling 1960: 43-4).

Revealing information about one's own past illegality or committing new illegal acts can be a commitment device. Schelling's idea has been invoked and/or tested to explain cooperation among paedophiles online (Gambetta 2009: 66), academics in low quality educational systems (Gambetta 2009; see also Varese 1996), Mafia organizations (Campana and Varese 2013), deviant adolescents (Flashman and Gambetta 2014), corrupt agents (Gambetta 2018), and cybercriminals (Lusthaus 2018: 132-3).

Surely, no mechanism is perfect and to some extent trust still plays a role. As we cannot absolutely certain that our partner will abide by his promise, we must take a leap in the dark, yet we try to make that leap as small as possible. Ultimately, when we trust somebody above and beyond the assurance she has given us, we overestimate her intentions and hope for the best (Yamagishi and Yamagishi 1994: 136 defy trust as a bias in processing information). This paper is a study of the mechanisms that have been found to ensure cooperation among people who do not readily trust each other: reputation-building; repeated interaction; hostage-taking; and sharing compromising information. Below (Section 5) we explore qualitatively whether such mechanisms are at work in the case of IVTS in China.

\section{Methods and Data}

This study of IVTS in China is based primarily on qualitative interviews with individuals directly involved and/or with extensive knowledge of the industry. We conducted 22 interviews in 
Zhuhai, Macau and Hong Kong and undertook several field trips to Zhuhai, writing some 100 pages of field observations. We chose Zhuhai as the main site of our field trips because it is one of 'the major underground conduits for Chinese hot money' (Pomfret and Miller 2013).

\section{(Figure 2 and Photo 1 \& 2 here)}

The majority of our respondents in Zhuhai operate in the Gongbei underground mall, located next to the border crossing, while some work in what is known as Bar Street, slightly outside the centre of town. IVTS operate in the open, as reported in Chinese media, and it was not hard to speak to them (see e.g. Liu, Yang and Yin 2015; Zhang 2014). An interviewee told Shanghai Securities News: 'you will know if you pass through Gongbei border, it is like a market there with the underground banks' (Shanghai Securities News 2012).

When we went, it was relatively easy to locate informal banks. Although they were disguised as local convenience stores, it was clear that no items were being bought and sold. The only item on display was a desk calculator. We could see people changing money. Invariably, we were invited into the back room as soon as we explained what we were looking for. On each occasion, a more senior/older member of the IVTS was happy to speak to us. If one of the interviewees could not answer questions regarding the commission fee, he would call his colleagues while we waited in the shop. Most of the IVTS we visited gave us a business card and some even hand-wrote the mobile telephone number of their staff for us. They were happy to talk to us, even though we made clear that we were researchers rather than customers. Over time, we discovered IVTS in other parts of Zhuhai, although the majority of the city's IVTS were located close to the Gongbei crossing. The ease of locating the interviewees and their willingness to share information was an indicator of how open the industry is in Zhuhai. In addition, we managed to interview people who had used the services of IVTS in Macau and Hong Kong. For comparative purposes, we also interviewed individuals who used other IVTS in Hong Kong. It should be added that some shops we approached turned out to offer currency exchange services only, not money transfers (B-6; B-7; B-8; B-9).

This study also relies on newspaper reports published in China and abroad, and official documents. We conducted a systematic search of two Chinese-language databases: China Core Newspapers Full-text Database and China Judgements Online. In doing so, we collected 189 
news articles and 471 cases that were relevant to underground banks and money laundering. With the help of research assistants, we identified 12 news articles and 14 cases relevant to this paper. We also searched the Xinhua.net webpage and websites of China's leading business newspapers, including 21st Century Business Herald, Business Times, Caijing, China Business News, the Southern Weekend and Economic Observer. We found 215 online articles, nine of which are directly related to this paper. In addition, searches using Google and Baidu helped us identify a further dozen helpful articles. Online articles and newspaper reports helped us validate interviewee responses and discuss additional cases.

\section{State Control and IVTS in China}

The intervention of the state in economic life, as noted by Portes and Haller (2010: 409), produces two completely different outcomes: on the one hand, it "creates a "formal space" of predictable and enforceable transactions where modern capitalism can flourish'; on the other hand, it can 'expand the very conditions' that give rise to unregulated activities. The widespread use of IVTS in China offers a good example of the paradox of state control. The People's Republic of China has placed strict controls on the movement of capital by both corporations and individuals. Payments by individuals to foreigners are capped at USD 50,000 a year. The limit for Chinese nationals converting Chinese RMB into foreign currency is also set at USD 50,000 per year. ${ }^{1}$ Only a maximum of RMB 20,000 (USD 3,200) can be legally carried out of China, and an individual can withdraw no more than RMB 10,000 (USD 1,600) per day from cash machines abroad (Pomfret and Miller 2013; Zabielskis 2015). ${ }^{2}$

Yet there is a significant illegal capital outflow from China. The think-tank Global Financial Integrity has calculated that China has the highest cumulative illicit financial outflow in the world, in the region of USD 1.08 trillion between 2002 and 2011. According to a 2008 report by the People's Bank of China, between 16,000 and 18,000 officials, businessmen, CEOs and others have 'disappeared, carrying about 800 billion yuan' since the mid-1990s (cited in Pomfret and Miller 2013). According to an estimate cited by Wee (2014), more than a million officials and their families have moved assets offshore in the last five years. High-profile investigations by The International Consortium of Investigative Journalists and The New York Times have exposed extensive use of offshore companies to hide assets by members of the political and economic 
elite, leading to government retaliation against the journalists (Barboza, Silver-Greenberg and Protess 2013 and Guevara et al. 2014). ${ }^{3}$

Those who want to gamble significant sums need to bypass official channels. In addition, some individuals simply want to take the proceeds of crime, most notably bribes, across the border. It is often the case that corrupt officials use their position to acquire funds to gamble in Macau. In addition, we were told that Chinese students studying at the University of Macau use the system simply to have cash available in term-time $(\mathrm{C}-8)$.

Illegal transfers to China also exist and the funds are used to buy raw materials or pay wages, bypassing the lengthy procedures required by official banks. A Hong Kong businessperson explained the difficulties of trusting the Chinese banking system: 'One of the biggest problems with conducting business on the Mainland is the difficulty of getting money in and out. Most people who do business in China, mainland Chinese included, do not want to keep too much money in China because they do not trust the system and the people within. [...] Hence, I need to transfer money out of China as soon as I have paid off the costs' (C-7). A factory boss interviewed by Pomfret and Miller (2013) was pleased with the ease of transfer: 'It just takes fifteen minutes [to transfer money through an IVTS agent], but official approval can take two weeks,'.

We conducted an interview with an informal banker operating out of a shop located inside the underground mall at the Gongbei-Macau crossing. The IVTS was concealed as an outlet selling outdated phone accessories. For example, the shop had a display of iPhone 4 protective cases, while at the time of the visit (October 2015) the latest model, used also by the shopkeeper, was iPhone 6. Most tellingly, we observed a member of the public coming up to the desk and asking to buy a carton of cigarettes, which was also on display. The sales assistant said that the item was not for sale, only for show (B-2). The shop consisted of two areas: the front and the back. It caught our attention because we could see a group of men in their 20s with stacks of Chinese currency in the back room: the door was slightly ajar when we passed and they made no effort to shut it even though it was a busy section of the mall (B-2). The IVTS shops we saw had two types of easily recognizable signs: '[name] merchant shop' and 'we help you send/we help you receive.' 
The service consisted of the following: the customer gives RMB to the service provider in Gongbei and then their organization delivers Hong Kong dollars in Macau (several interviewees; see also Pomfret and Miller 2013). Respondents pointed out that the cash-only service would be available 'immediately' (B-1; see also B-4). One told us he could make the cash 'fly across' (B11). Customers concurred, noting that IVTS are faster than official banks (e.g., C-5; C-6; C-7).

Some IVTS ask for a fee. Calabee, who operated a nail polish salon and, with her husband, an IVTS shop, quoted us a fee of RMB 300 for the transfer of RMB 300,000 (B-1). ${ }^{4}$ She added that she could also transfer the money back from Macau to China, if needed (B-1). The transfer from Hong Kong to China would occur in currency exchange shops (C-5; C-6).

Beside the cap on the amount that can be transferred, official banks offer individual customers a less favourable rate, take longer to make the transfer, and require complex documentation for the transaction. Table 1 compares the exchange rate offered, transaction costs, time and paperwork required by different institutions. 


\section{(Table 1 here)}

Informal bankers in Gongbei appear to transfer significant sums. A man named Choi told Reuters journalists: 'We can move tens of millions each day' (Pomfret and Miller 2013). Calabee told us that she would not normally deal with less than one million RMB (circa USD 16,000 in 2015), while her husband only dealt with much larger sums (B-1; other shops in Gongbei accepted minimum transfers of 800,000 RMB, e.g. B-10). For larger sums, Calabee might split the transfer into smaller amounts. A former IVTS operator (who now manages a restaurant on the outskirts of Zhuhai) explained that he previously used to carry money across the ZhuhaiMacau border, doing several runs per day with a couple of million dollars each time, and commented that 'it is normal and people do it every day' (B-12). Other shops, both in the Gongbei mall (B-11) and in Bar street (B-4), said they were willing to transfer RMB 100,000.

A movie distributor based in Hong Kong and working in China told us that the entertainment industry often uses IVTS to transfer money across the border: 'It is a waste of time to transfer less than RMB five million (USD 80,277). That is why the commission fee is so small, because the sums transferred are very large' (C-1). The Ministry of Public Security has estimated that underground banks handled more than USD 137 billion in transactions in 2016 (Wee 2017).

Once the money has been given to service provider 1, it appears that there are two ways to retrieve it on the other side of the border. One way mentioned in several interviews uses VIP room accounts in Macau casinos. A peculiar system of VIP 'rooms' operates in Macau's casinos. They are the equivalent of private clubs and are housed inside the most prestigious hotels. These establishments issue their own chips (so-called 'dead-chips' or 'clay chips') and an account can be opened there. VIP-room chips are non-negotiable and cannot be redeemed for cash in the main casino. Normally the chips are loaned to customers for a commission of 0.7 per cent (Godinho 2006; Lo and Kwok 2017; Veng Mei Leong 2002; Wang and Eadington 2008; Wang and Zabielskis 2010). A VIP room functions, in effect, as a cash dispenser: 'It operates like a bank. You can take money in and out at any time,' said a respondent (Pomfret and Miller 2013). We visited several VIP rooms and saw people at counters presenting slips of paper and their passports to withdraw money. 'I have an account at the $X X$ VIP room in Macau. You can either ask someone to withdraw the money for you, or I can just transfer the money from my account to your account in the same VIP room if you have an account,' Calabee told us (B-1). Other 
respondents confirmed this mechanism, involving the same VIP room (see e.g. B-2; B-4; B-5; B10; B-11. One respondent-B-1-mentioned a different VIP room).

Having outlined how IVTS works in the Chinese region bordering Macau and Hong Kong, we turn to the role that trust and credible commitments play in facilitating the exchange, and the strategies used by service providers to signal their trustworthiness.

\section{Informal Value Transfer Systems, and Credible Commitments in China}

When we interviewed an informal banker in Zhuhai who doubles as a restaurant owner, he readily said that 'the bottom line of this job is for the customer to trust me' (B-12). Indeed, trust in service provider 1 is crucial: s/he has to convince customer 1 (and service provider 2) to part with money before she can prove she has complied with the informal deal. How does service provider 1 increase the likelihood that customer 1 will give her his money? Several strategies were mentioned by our respondents. One is to reduce the uncertainties of the transfer to a minimum. A banker suggested the following to a customer:

You can watch me make the phone call [to transfer the money] from this room to one of my guys in Macau, check the number I dialled, then I give you this same number and you can call him when you cross the border to Macau to pick up the money from him (B-5).

Another advised the customer to ask a friend in Macau to pick up the money. Once the instruction to transfer money had been placed in Zhuhai, the money was ready in less in fifteen minutes and customer 2 could pick up the money and inform customer 1 that the transaction has been completed. Customer 1 waits with service provider 1 until the transaction is done.

Respondent B-2 - who uses the VIP-room system - said that customer 2 could stand by the counter at the VIP room in Macau to ensure that the money is there and call back customer 1 in Zhuhai.

Another strategy consists of transferring the money before the customer hands over the cash to the service provider. This is reportedly the strategy used by Ge Liang from Shanghai. 'This approach made every customer feel safe and confident, and it has helped Ge Liang win a steady 
stream of customers. In just two years, the turnover has reached a total of 2 billion RMB' (Xi 2014).

A degree of uncertainty still remains, however. The money could be counterfeit, or the banker could still find an excuse to abscond.

Calabee told us: 'I have a large shop here in the mall. You can always come back and check on me if there is a problem. I am not going anywhere' (B-1). She also encouraged us to ask around, compare services and check her reputation out (B-1). While stated as a matter of fact, Calabee was pointing to two mechanisms that would increase the trust of customer 1, namely hostagetaking and reputation. She had invested so heavily in her shops (including a nail polish salon) that it would not make sense for her to run away with the customer's money. In addition, she was showing confidence in her services by encouraging us to shop around. A Hong Kong woman doing business in China also told us that the person she uses 'never shows any concern that his customers might leave him, he is not pushy'. This attitude increases her confidence in him (C-7).

One respondent mentioned that 'larger spaces and more staff' increase confidence (C-8), as does lowstaff turnover (C-8). The respondent continued by highlighting the importance of repeated interaction: 'One of the underlying norms of this industry is try to avoid hiring new staff. If they recognize you as a frequent customer, they give you more benefits' (C-8). In addition, age and gender of staff matters: they are mostly 'young females or mature males. [...] I think that age and gender are the factors that do have influence in this business.' (C-8).

Stability is an important signal for customers who use informal banks. An interviewee mentioned that:

A fixed place of business is very important for both informal banks and customers. I am a regular customer of the $\mathrm{XX}$ foreign currency exchange shop that helps me transfer money to and from mainland China. In mid-2017, when I filled out the remittance slip, the staff in reception told me they were moving to a new location opposite the nearby Bank of China. She asked me to go there next time, I felt that it was very strange because the shop has been based there for many years. But then I found that they didn't move elsewhere in the end. I asked the staff member in reception why; she did not explain and just told me that they would stay in the same place forever...I would feel unsafe or suspicious if the shop moved 
to a new place. There are a lot of foreign currency exchange shops nearby, I would probably use another shop. (C-3)

A combination of hostage-taking and reputation mechanisms can be detected in the way IVTS make use of employees of official banks in China. These employees introduce customers whose demands cannot be met by formal channels to underground bankers, often in the lobby of the bank. Xinhua News Agency reported:

In the case of a Shenzhen underground bank involving more than 12 billion Chinese RMB, Mr Shen, the then director of a Shenzhen Baoan bank branch, advised Chen Da, a Hong Kong-based businessman, to transfer huge amounts of money overseas through underground banks. A large number of 'clients' involved in this case confirmed that the reason why they chose to rely on underground banks was due to the introduction made by bank employees or other friends (Jiang and Zou 2015).

Since the general public trusts state-owned banks, the involvement of bank employees in IVTS not only brings customers to underground banks but also makes the illegal services supplied by underground banks appears to be more reliable. Customers' confidence is increased if employees from state-owned banks suggest a particular service provider. It should be added that formal banks are also fixed establishments to which customers can go back and complain if things go wrong.

Sharing of compromising information is also at play. In China, businesspeople and government officials regard engagement in shared activities (e.g. social drinking) as an essential way to cultivate affective attachment and mutual trust. According to Barbalet (2017: 8), 'since post-Mao marketization, shared consumption of commercial sex as well as banqueting and drinking serve the purpose of generating ganqing [emotional attachment] among businesspersons and between businesspersons and officials' (see also Zheng 2009: 137-42). Yet it remains illegal to consort with prostitutes and raids do occur in establishments where businessmen consume paid-for sex (Jeffreys 2004; Zheng 2009). Underground bankers who accept prostitution services are in effect sharing compromising information with the VIP customers with whom they are trying to build trust. In March 2017, Initium Media, a Hong Kong-based digital media outlet, published an interview with $\mathrm{Mr} \mathrm{Ho}$, an informal banker conducting business in mainland China: 
[Mr Ho] said that he had five VIP customers in the mainland, four businessmen and one township cadre in Zhongshan [a city in the province of Guangdong, China]. Speaking of the township official, Mr Ho shared his 'unforgettable' experience by saying: 'Each time I visited Zhongshan, he always greeted me with unpalatable dishes...At night, he invited me to go to a nightclub and we consumed commercial sex together. Those sex workers are extremely ugly, but there is no way to reject. I have to accept his kindness willingly in order to get business opportunities (Chen 2017).

In conclusion, providers of IVTS are keenly aware they have to signal their trustworthiness to customers and adopt several strategies to do so. Firstly, they try to minimize the time it takes to transfer money. Secondly, and most interestingly, they emphasize their ownership of significant fixed establishments, a strategy we interpret as a form of hostage-taking: 'since we have a shop we cannot take away with us, we are in effect hostages to our customers, and we will be here to answer their questions and complaints'. Thirdly, providers of IVTS enlist the help of employees of official banks, riding on the reputation of state institutions. Such establishments are also fixed and customers can go back to seek clarification and complain if necessary. Finally, some service providers socialize and consume commercial sex with prominent customers, a practice we interpret as an instance of the 'sharing of compromising information' mechanism.

\section{Conclusions}

This paper is a study of trust and credible commitments among IVTS in China. IVTS work as follows: a customer 1 giver her money to service provider 1, who in turn gives her a code. In a different locale, customer 2 collects the money after presenting the code from a service provider 2. At a later point in time, service provider 1 will reimburse service provider 2 . While most authors stress the importance of trust in this exchange, we argue that service provider 1 will try his best to show the customer that he is credibly committed to his promise, thereby reducing the need to blindly trust him. The paper identifies four four mechanisms that can foster cooperation among individuals who do not trust each other: reputation; repeated interaction; hostage-taking; and sharing compromising information.

In the second part of the paper, we explore whether IVTS operators use credible commitments to increase the confidence of their customers in China. We have chosen China because of the strict 
rules on money transfers out of the country and reports of massive illegal outflow of capital. In the past few years, the Chinese government has seen IVTS as a serious threat to the stability of the currency $(\mathrm{XX})$. We have conducted several field trips to the Chinese region bordering Hong Kong and Macau and interviewed several bankers and their customers. The paper details first how the transfers occur, in a context where transferring money abroad is capped and costly. We then outline the strategies used by service providers to increase confidence in their business. First, they try to reduce to a minimum the time of the transfer and in some cases, and they are even willing to pay out the cash to customer 2 before customer 1 hands his money to service provider 1. Second, bankers stress that they have fixed and reputable establishments, in the form of shops. These establishments can be seen a way to bind the service provider to his promise: service provider 1 cannot simply run away with the money from a single transaction. He would forgo more value than could be gained by cheating in the one-off interaction with customer 1 . We interpret this as a 'hostage-taking' mechanism. Third, service providers recruit bank employees, riding on the reputation of official banks. These employees entice customers in bank lobbies and direct them towards IVTS. Customers can go back to the bank and demand an explanation if something goes wrong, thus both reputation and hostage-taking mechanisms are at work. Finally, informal bankers engage in social drinking and consumption of commercial sex with high-profile customers. Since prostitution is illegal in China, service providers compromise themselves by accepting the offer of commercial sex, yet they do it to foster cooperation with customers. We have not come across instances of violence used in this sector, nor the presence of a third-party enforcer such as the Mafia. While we cannot completely exclude the possibility that violence is used and some gangs are active in this market, we conclude that the informal arrangements described here are highly effective and make the system work on the basis of effective display of informal credible commitments. The strategies we have uncovered underpin cooperation in a large, illegal sector of the Chinese economy, transferring billions of dollars out of China every year. 
Informal bankers, all Chinese nationals

B-1 Female (Gongbei mall, Zhuhai, 15-16.08.2015)

B-2 Female (Gongbei mall, Zhuhai, 15.08.2015)

B-3 Male (Gongbei mall, Zhuhai, 15.08.2015)

B-4 Male (Bar street, Zhuhai, Zhuhai, 15.08.2015)

B-5 Male (street opposite hotel, Zhuhai, 16.08.2015)

B-6 Female (currency exchange shop staff, Zhuhai, 06.2015)

B-7 Female (currency exchange shop staff, Zhuhai, 06.2015)

B-8 Female (currency exchange shop staff, Zhuhai, 06.2015)

B-9 Male (currency exchange shop staff, Zhuhai, 06.2015)

B-10 Female (Gongbei Mall, Zhuhai, 08.2015)

B-11 Male (Gongbei mall, Zhuhai, 08.2015)

B-12 Male (Zhuhai, restaurant, 08.2015)

\section{Customers}

C-1 Female, movie industry executive (Hong Kong, 10.2015)

C-2 Male, businessman (Hong Kong, 08.2017)

C-3 Male, teacher (Hong Kong, 08.2017)

C-4 Male, academic (Hong Kong, 08.2017)

C-5 Female, paralegal (Hong Kong, 08.2017)

C-6 Male, law researcher (Hong Kong, 08.2017)

C-7 Female, businesswoman (Hong Kong, 08.2017)

C-8 Male, businessman (Hong Kong, 08.2017)

\section{Others}

P-1 Official (Hong Kong, 10.2015)

FB-1 1 Investment banker (Hong Kong, 08.2017)

\section{References}

Allen, J. (2006), Hostage and Hostage-taking in the Roman Empire. Cambridge University Press.

Axelrod, R. (1984), The Evolution of Cooperation. Basic Books.

Ballard, Roger. (2003), 'Hawala Transformed: Remittance-driven Transnational Networks in the post-Imperial Economic Order', Center for Applied South Asian Studies, University of Manchester, available online at:

http://www.casas.org.uk/papers/pdfpapers/transformed.pdf. 
Barbalet, J. (2017), 'Guanxi as Social Exchange: Emotions, Power and Corruption', Sociology, doi: $10.1177 / 0038038517692511$.

Barboza, D., Silver-Greenberg, J., and Protess, B. (2013), ‘JPMorgan's Fruitful Ties to a Member of China's Elite', New York Times, available online at https://dealbook.nytimes.com/2013/11/13/a-banks-fruitful-ties-to-a-member-of-chinaselite/.

Campana P (2011) Eavesdropping on the Mob: the functional diversification of Mafia activities across territories. European Journal of Criminology 8(3): 213-228.

Campana, P. (2018), 'Out of Africa: The Organisation of Migrant Smuggling across the Mediterranean', European Journal of Criminology, 15/4: 481-502.

Campana, P., and Varese, F. (2013), 'Cooperation in Criminal Organizations: Kinship and Violence as Credible Commitments', Rationality and Society, 25/3: 263-89.

Chen, J. (2017), 'The Broker has Personally Asked for New Recruits. How does Hong Kong Become an RMB Outflow Transfer Station?', The Initium, available online at https://theinitium.com/article/20170310-hongkong-China-s-capital-outflow/ (in Chinese).

Coase, R. H. (1937). The nature of the firm. Economica, 4(16): 386-405.

Cook KS, Hardin R and Levi M (2005) Cooperation without trust? Russell Sage Foundation.

Flashman, J., and Gambetta, D. (2014), 'Thick as Thieves: Homophily and Trust among Deviants', Rationality and Society, 26/1: 3-45.

Frye, T., and Shleifer, Ai. (1997), 'The Invisible Hand and the Grabbing Hand', the American Economic Review, 87/2: 354-8.

Gambetta D (1993) The Sicilian Mafia. Harvard University Press.

Gambetta, D. (2009), Codes of the Underworld. How Criminals Communicate. Princeton University Press.

Gambetta, D. (2018), 'Why is Italy Disproportionally Corrupt?: A Conjecture', in K. Basu and T. Cordella, eds., Intitutions, Governance and the Control of Corruption, 133-64. Springer International Publishing.

Godinho, J. (2006), 'Credit for Gaming in Macau', Gaming Law Review, 10/4: 363-8.

Goitein, S. (1967-1993), A Mediterranean Society: the Jewish Communities of the Arab World as Portrayed in the Documents of the Cairo Geniza (6 vols.). University of California Press.

Guevara, M. W., Ryle, G., Olesen, A., Cabra, M., Hudson, M. and Giesen, C. (2014), 'Leaked Records Reveal Offshore Holdings of China's Elite', International Consortium of Investigative Journalists, available online at https://www.icij.org/investigations/offshore/leaked-records-reveal-offshore-holdings-ofchinas-elite/

Hardin, R. (1991). Trusting persons, trusting institutions. In R.J. Zeckhauser (ed.), Strategy and choice. MIT Press, 185-209.

Hariharan, A. (2012), 'Hawala's Charm: What Banks can Learn From Informal Funds Transfer Systems', William \& Mary Business Law Review, 3/1: 273-308.

Hart, O.D. (1988), 'Incomplete Contracts and the Theory of the Firm', Journal of Law, Economics, \& Organization, 4/1:119-39.

Hobbes T (1651) Leviathan. London: Penguin Classics, 1982.

Ismail, A. A. (2007), 'Lawlessness and Economic Governance: the Case of Hawala System in Somalia', International Journal of Development Issues, 6/2: 168-85.

Jeffreys, E. (2004), China, sex, and prostitution. Routledge. 
Jiang, L., and Zou, W. (2015), 'More than 800 Billion Yuan Transferred in 7 Months by an Underground Money House which has Become a Corrupt Money Laundering Machine', Xinhuanet, available online at http://www.xinhuanet.com/legal/201511/05/c_128397797.htm. (in Chinese).

Jost, P. M., and Sandhu, H. S. (2000), 'The Hawala Remittance System and its Role in Money Laundering', Interpol General Secretariat, available online at http://www.nmta.us/assets/docs/hawala.pdf

Kleemans, E.R., Brienen, M.E.I., van de Bunt, H.G., Kouwenberg, R.F., Paulides, G. and Barensen, J. (2002), Organized Crime in the Netherlands; Second Report of the WODCorganized Crime Monitor. The Hague: WODC. (In Dutch).

Klein, D. B. ed., (1997). Reputation: Studies in the Voluntary Elicitation of Good Conduct. University of Michigan Press.

Lindley, A. (2009), “Dirty Money” and "Development Capital": Somali Money Transfer Infrastructure under Global Scrutiny', African Affairs, 108/433: 519-39.

Liu, Y., Yang, C., and Yin, J. (2015), 'Copying Mobile Phone Cards to Steal 14 Million, Final Judgement for the First Money Laundering Case in the City of Xiangtan', Netease, available online at http://news.163.com/15/0710/10/AU5G66TG00014AEE.html. (in Chinese).

Lo, T. W., and Kwok, S.I. (2017), 'Triad Organized Crime in Macau Casinos: Extra-legal Governance and Entrepreneurship', The British Journal of Criminology, 57/3: 589-607.

Lusthaus, J. (2018), Industry of Anonymity: Inside the Business of Cybercrime. Harvard University Press.

Maimbo, S. M. (2003), 'The Money Exchange Dealers of Kabul', World Bank Working Paper No. 13, available online at http://citeseerx.ist.psu.edu/viewdoc/download?doi=10.1.1.201.9600\&rep=rep1\&type=pdf

NCTA (The National Commission on Terrorist Attacks). (2004), 'The 9/11 Commission Report', available online at http://www.9-11 commission.gov/report/911Report.pdf.

North, D. C. (1993). Institutions and credible commitment. Journal of Institutional and Theoretical Economics (JITE)/Zeitschrift für die gesamte Staatswissenschaft, 11-23.

Passas, N. (1999), Informal Value Transfer Systems and Criminal Organizations: A Study into So-called Underground Banking Networks. Dutch Ministry of Justice.

Passas, N. (2003), 'Hawala and Other Informal Value Transfer Systems: How to Regulate Them?', Risk Management: An International Journal, 5/2: 49-59.

Passas, N. (2005), Informal Value Transfer Systems and Criminal Activities. Ministry of Justice.

Pomfret, J., and Miller, M.. (2013), 'Despite Curbs, China's Vast Hot Money Triangle Flourishes', Reuters News Agency, available online at https://www.reuters.com/article/uschina-laundering-triangle-insight-idUSBRE94I0CB20130519.

Portes, A., and Haller, W. (2010), 'The Informal Economy', in N. J. Smelser and R. Swedberg, eds., The Handbook of Economic Sociology, 403-25. Princeton University Press.

Raub, W., and Weesie, J. (1990), 'Reputation and Efficiency in Social Interactions: An Example of Network Effects', American Journal of Sociology, 96/3: 626-54.

Richards, D. S. (1970), Islam and the Trade of Asia: A Colloquium. University of Pennsylvania Press.

Shapiro, D. L., Sheppard, B. H., \& Cheraskin, L. (1992). Business on a handshake. Negotiation journal, 8(4): 365-377.

Schelling, T. (1960), The Strategy of Conflict. Harvard University Press. 
Schelling, T. (2006), Strategies of Commitments and Other Essays. Harvard University Press. Shanghai Securities News. (2012), 'Underground Money House', available online at http://news.cnfol.com/121129/101,1591,13801178,00.shtml. (in Chinese). and http://www.p5w.net/news/gncj/201211/t4607769.htm. (in Chinese).

Siegel, D., and van de Bunt, H. (2014), 'Underground Banking in the Netherlands', in S. Caneppele and F. Calderoni, eds., Organized Crime, Corruption and Crime Prevention. Essays in Honor of Ernesto U. Savona, 251-61. Springer.

Skarbeck D (2011) Governance and Prison Gangs. American Political Science Review 105: 702716.

Skarbek, E. (2008), 'Remittances and Reputations of Hawala Money Transfer Systems: SelfEnforcing Exchange on an International Scale', Journal of Private Enterprise, 24/1: 95117.

Thompson, E. (2006), 'The Nexus of Drug Trafficking and Hawala in Afghanistan', in D. Buddenberg and W.A. Byrd, eds., Afghanistan's Drug Industry: Structure, Functioning, Dynamics and Implications for Counter-narcotics Policy, 155-88. UNODC and World Bank.

Thompson, E. (2008), 'An Introduction to the Concept and Origins of Hawala', Journal of the History of International Law, 10: 83-108.

Turnell, S., Vicary, A., and Bradford, W. (2008), 'Migrant-worker Remittances and Burma: An Economic Analysis of Survey Results', in M. Skidmore and T. Wilson, eds., Dictatorship, Disorder and Decline in Myanmar, 63-86. ANU E Press.

van de Bunt, H. (2008). 'The Role of Hawala Bankers in the Transfer of Proceeds from Organized Crime', in D. Siegel and H. Nelen, eds., Organized Crime: Culture, Markets and Policies, 113-26. Springer.

Varese, F. (1996). Ecomia di idee presso il professor Stefano Zamagni. Belfagor 51(2): 169-185. Retrieved from http://www.jstor.org/stable/26147826

Varese F (2001) The Russian Mafia: Private Protection in a New Market Economy. Oxford University Press.

Veng Mei Leong, A. (2002), 'The Bate-Ficha Business and Triads in Macau Casinos', Queensland U. Tech. L. \& Just. J., 2: 83-97.

Wang, W., and Eadington, W. R. (2008), 'The VIP-room Contractual System and Macao's Traditional Casino Industry', China: An International Journal, 6/2: 237-60.

Wang, W., and Zabielskis, P. (2010), 'Making Friends, Making Money: Macao's Traditional VIP Casino System', in Sytze F. Kingma, ed., Global Gambling: Cultural Perspectives on Gambling, 113-43. Routledge.

Wee, S. L. (2014), 'Over 150 Chinese Economic Fugitives in the US', Macau Business Daily, 16.

Wee, S. L. (2017), 'China Busts a \$3 Billion Underground Bank as It Tightens Its Grip on Money', New York Times, available online at: https://www.nytimes.com/2017/11/23/business/china-underground-bank-3-billion.html

Williamson, O. E. (1983). Credible commitments: Using hostages to support exchange. The American Economic Review, 73(4): 519-540.

Yamagishi, T., \& Yamagishi, M. (1994). Trust and commitment in the United States and Japan. Motivation and emotion, 18(2): 129-166.

Xi, Z. (2014), 'Shanghai Extraordinary Underground Bank Case', Hong Kong Phoenix Weekly, available online at: https://www.cc362.com/content/zpvY7yoWa4.html. (in Chinese). 
XX. XXX. [title withheld]

Zabielskis, P. (2015), 'Too Big to be Bad? Implications for Theory and Review of Research on Crimes, Vices, and Misdeeds in the Casino Culture of Macau', Crime, Law and Social Change, 64/2-3: 127-152.

Zhang, D. (2014), 'Police Officers from Guangdong, Hong Kong and Macau Join Hands to Fight Organized Crime, 546 Criminal Suspects have been Arrested within Two Months', China News Service, available online at http://www.hb.chinanews.com/news/2014/1229/199122.html. (in Chinese).

Zheng, T. (2009), Red Lights. The Lives of Sex Workers in Post-socialist China. University of Minnesota Press. 
Figure 1. Stages in a typical informal banking exchange

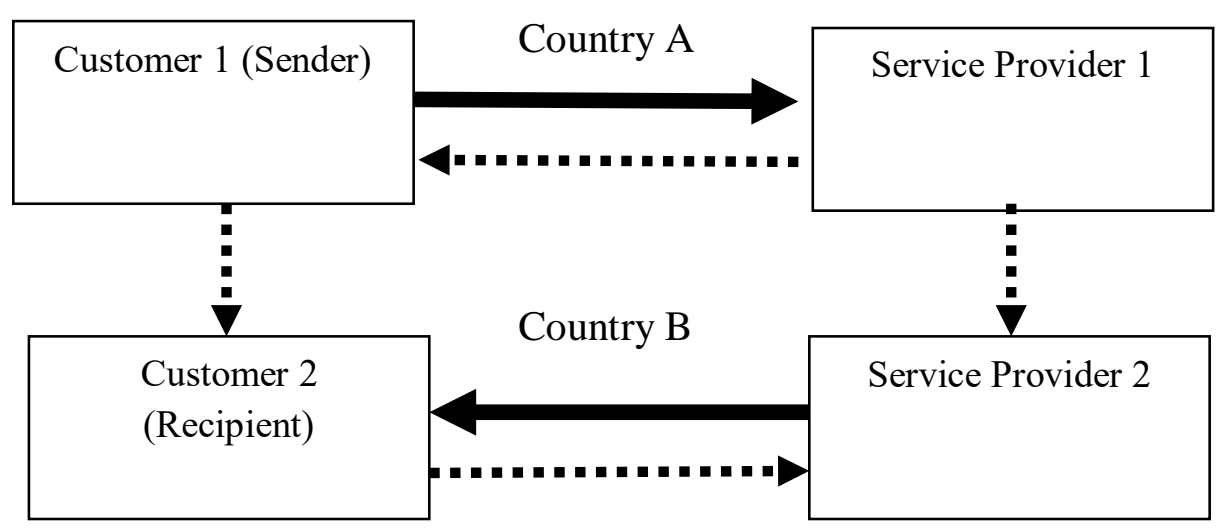

Source: XX.

Note: The solid lines refer to the transfer of money or value. The dotted lines refer to the exchange of information on the amount to be transferred and the code. 
Figure 2. Map of Fieldwork Cities

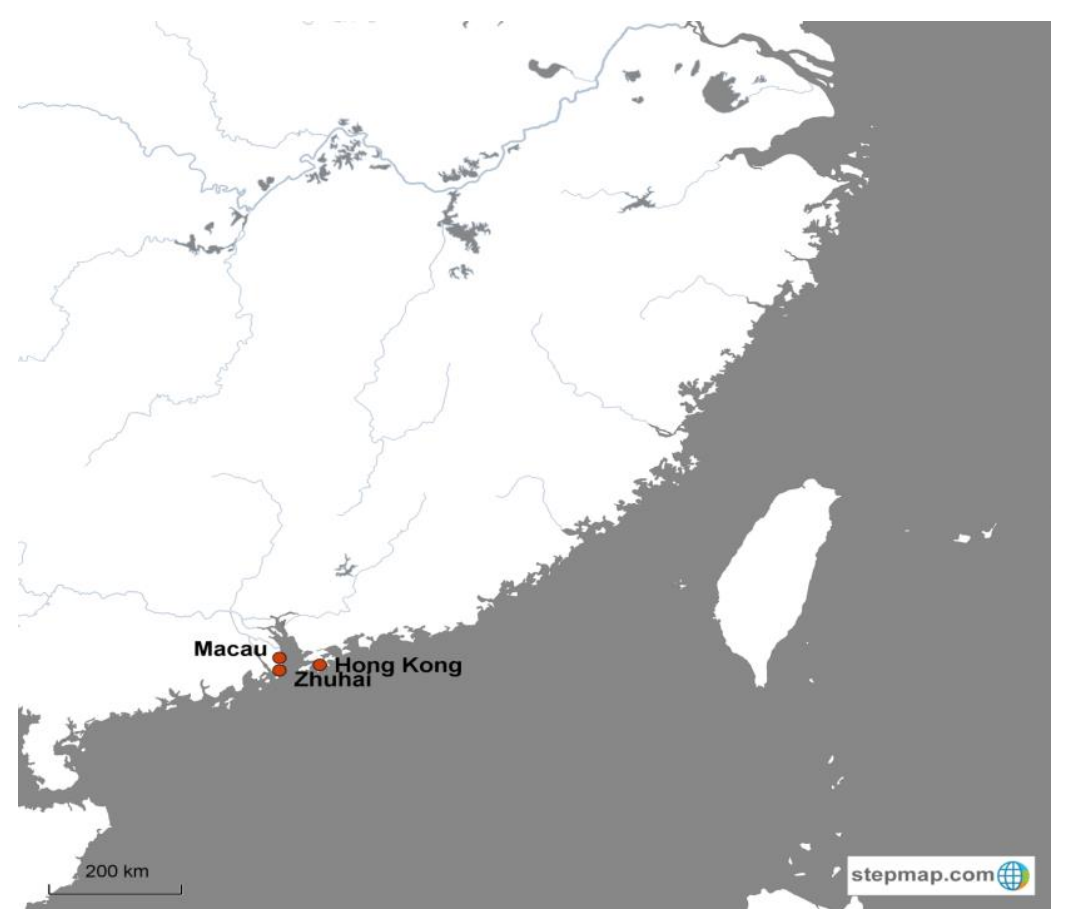


Photos $1 \& 2$.
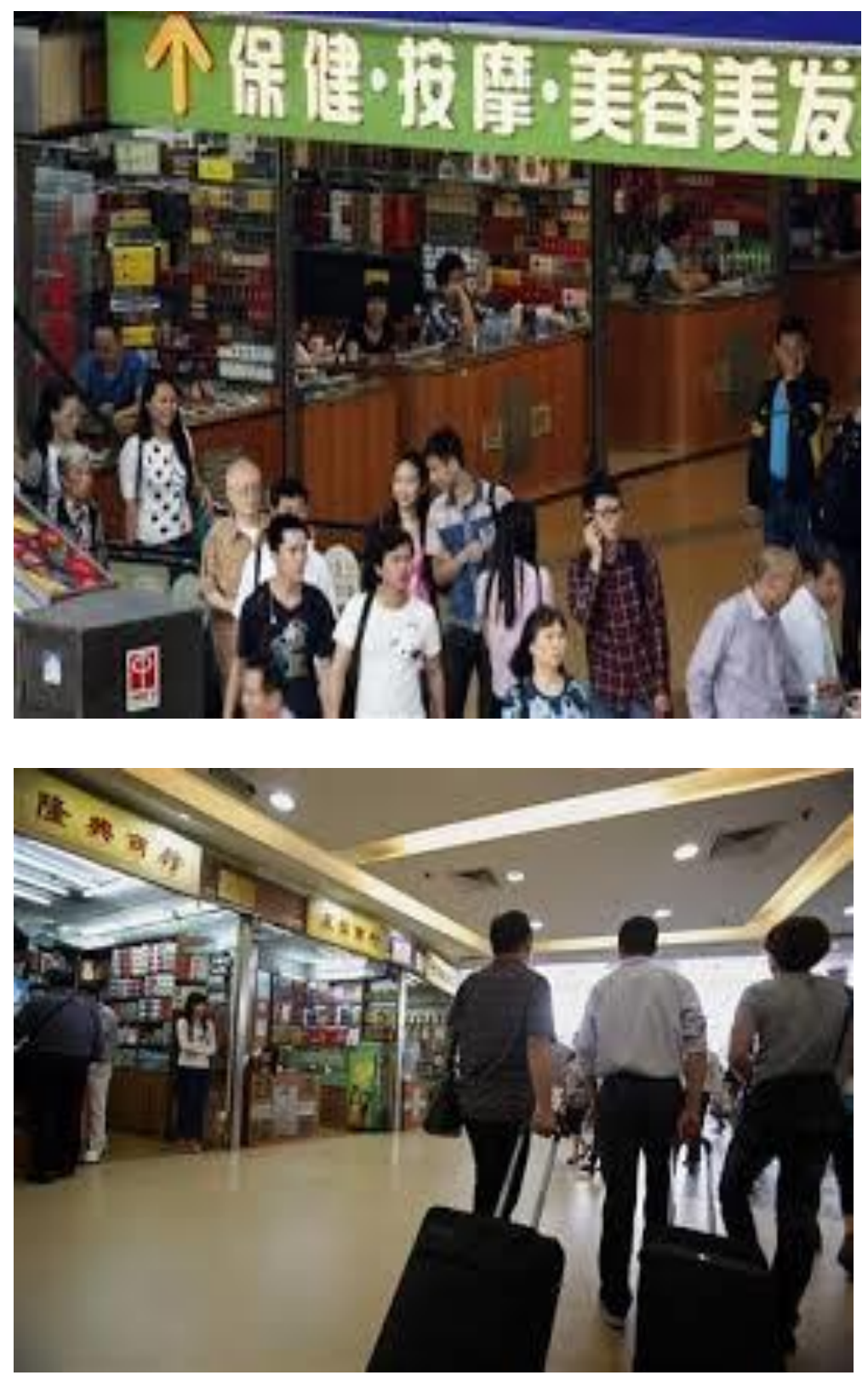

Shoppers walk past IVTS in the Gongbei underground mall in Zhuhai, China. Photo:

REUTERS/Staff. The sign on Photo 1 shows a massage parlour and beauty salon. Photo 2 shows merchant shops. 
Table 1. Exchange rate offered, transaction costs, time and paperwork required to transfer money

\section{by different institutions (June 2018 data)}

\begin{tabular}{|c|c|c|c|c|c|}
\hline Banks & $\begin{array}{l}\text { Exchange rate } \\
\text { from HK dollars } \\
\text { to } \mathrm{RMB}\end{array}$ & $\begin{array}{l}\text { Transaction cost to } \\
\text { China from Hong } \\
\text { Kong (including } \\
\text { commission fees) }\end{array}$ & $\begin{array}{l}\text { Transaction cost from } \\
\text { Hong Kong to China }\end{array}$ & $\begin{array}{l}\text { Time required to } \\
\text { transfer to personal } \\
\text { account }\end{array}$ & Paperwork required \\
\hline $\begin{array}{l}\text { Bank of } \\
\text { China } \\
\text { (BoC) }\end{array}$ & $\begin{array}{l}\text { HKD to RMB } \\
0.82\end{array}$ & $\begin{array}{l}\text { There is no } \\
\text { restriction on } \\
\text { transferring money } \\
\text { from mainland China } \\
\text { to a Hong Kong BOC } \\
\text { account., but the } \\
\text { bank advises that you } \\
\text { should consult the } \\
\text { bank in China for } \\
\text { more details }\end{array}$ & $\begin{array}{l}\text { Maximum transfer of } \\
\text { RMB 80,000 (USD } \\
\text { 12,494.14) per day to a } \\
\text { private bank account } \\
\text { under the same name } \\
\text { Handling charge: } \\
\text { At BOC branches: HKD } \\
210 \text { (USD 26.77) } \\
\text { Online: HKD 105 (USD } \\
\text { 13.39) }\end{array}$ & $1-3$ working days & $\begin{array}{l}\text { HKID card } \\
\text { Set up an RMB bank } \\
\text { account under the same } \\
\text { name in HK and China } \\
\text { with BoC (with valid } \\
\text { identification } \\
\text { documents and } \\
\text { statements }\end{array}$ \\
\hline HSBC & $\begin{array}{l}\text { HKD to RMB } \\
0.81125\end{array}$ & $\begin{array}{l}\text { No restriction on } \\
\text { receiving money } \\
\text { from mainland China }\end{array}$ & $\begin{array}{l}\text { Maximum RMB 80,000 } \\
\text { (USD 12494.14) per day } \\
\text { from Hong Kong HSBC } \\
\text { RMB account in Hong } \\
\text { Kong to HSBC } \\
\text { mainland China RMB } \\
\text { account under the same } \\
\text { name }\end{array}$ & $\begin{array}{l}\text { A few days to up to } 1.5 \\
\text { months }\end{array}$ & $\begin{array}{l}\text { Set up an RMB account } \\
\text { with HSBC (with valid } \\
\text { identification } \\
\text { documents and } \\
\text { statements) }\end{array}$ \\
\hline IVTS (1) & $\begin{array}{l}\text { HKD to RMB: } \\
0.811 \\
\text { As reference, } \\
\text { exact exchange } \\
\text { rate depends on } \\
\text { date of } \\
\text { transaction, can } \\
\text { check after } \\
\text { 10:45am each day } \\
\text { via WhatsApp or } \\
\text { WeChat }\end{array}$ & $\begin{array}{l}\text { No restriction on } \\
\text { receiving money } \\
\text { from mainland China }\end{array}$ & $\begin{array}{l}\text { No restriction on } \\
\text { transaction amount. } \\
\text { Handling charge if } \\
\text { amount is below HKD } \\
50,000 \text { (USD 6,373.97) }\end{array}$ & $\begin{array}{l}\text { From } 30 \text { minutes to } 2 \\
\text { hours }\end{array}$ & $\begin{array}{l}\text { Copy of HK ID and } \\
\text { proof of address of the } \\
\text { recipient }\end{array}$ \\
\hline IVTS (2) & $\begin{array}{l}\text { HKD to RMB: } \\
0.81 \\
\text { As reference, } \\
\text { the rate is better if } \\
\text { the transaction } \\
\text { amount is larger }\end{array}$ & $\begin{array}{l}\text { No restriction on } \\
\text { transaction amount } \\
\text { Share the copy of } \\
\text { receipt of transfer } \\
\text { from mainland to } \\
\text { Hong Kong via } \\
\text { WeChat, after which } \\
\text { the money can be } \\
\text { picked up at the store }\end{array}$ & $\begin{array}{l}\text { No restriction on } \\
\text { transaction amount } \\
\text { No handling charge is } \\
\text { needed for larger } \\
\text { remittances }\end{array}$ & $\begin{array}{l}\text { Within } 2 \text { hours if } \\
\text { transaction is } \\
\text { confirmed after } 11 \mathrm{am}\end{array}$ & $\begin{array}{l}\text { Transaction below } \\
\text { HKD 8,000 (USD } \\
1,019.84 \text { ) requires only } \\
\text { ID card }\end{array}$ \\
\hline
\end{tabular}


${ }^{1}$ The renminbi is the official currency of the People's Republic of China and is often abbreviated as RMB. In the period 2015-2017, the official exchange rate to the dollar was 622.84 (2015), 664.23 (2016), and 675.18 (2017).

${ }^{2}$ See also the information on the authorized government portal site to China at:

http://www.china.org.cn/english/LivinginChina/204171.htm

${ }^{3}$ This paragraph draws upon $\mathrm{XX}$.

${ }^{4}$ Other shops quoted fees ranging from RMB 300 (B-13) to RMB 260 (B-10) or RMB 250 (B11). 